\title{
MEDIA SOSIAL DAN DEMOKRASI DI ERA INFORMASI
}

\author{
Devie Rahmawati ${ }^{1}$ \\ ${ }^{1}$ Laboratorium Radio dan Komunikasi, Program Vokasi UI, devie.indonesia@gmail.com
}

Diterima : 11 Maret 2014

Layak Terbit : 3 Juli 2014

\begin{abstract}
Abstrak
Media sosial telah menjadi kekuatan baru dalam pembentukan ranah publik dewasa ini. Dibandingkan media konvensional, media sosial memiliki potensi yang lebih besar dalam produksi dan persebaran informasi secara lebih egaliter. Dengan kemampuan demikian, media sosial tentunya dapat berperan dalam penguatan demokratisasi dengan mengemansipasi publik untuk mengakses ranah publik. Melalui analisis terhadap ranah publik yang terbentuk, kita dapat melihat dengan jernih relasi antara media sosial dengan demokratisasi. Untuk keperluan tersebut tulisan ini mengadopsi konsepsi ranah publik Jurgen Habermas dan konsepsi korupsi ranah publik Mark E. Warren. Mengikuti Habermas, dalam menganalisis ranah publik kita harus memperhatikan dimensi komunikasi politik sekaligus ekonomi politik. Dalam hal ini, proses inklusi dan eksklusi di ranah publik juga harus diperhatikan agar kita dapat menilai apakah ranah publik kita koruptif atau tidak.
\end{abstract}

Kata kunci: media sosial, media konvensional, demokratisasi, ranah publik, korupsi.

\begin{abstract}
Social media has become a new force in shaping the public realm today. Compared to conventional media, social media has greater potential in the production and distribution of information in a more egalitarian. With such capabilities, social media can certainly play a role in strengthening democratization with emancipate the public to access public domain. Through an analysis of the public sphere is formed, we can see clearly the relation between social media with democratization. For the purposes of this article adopt Jurgen Habermas's conception of the public sphere and the public sphere corruption conception Mark E. Warren. Following Habermas, in analyzing the public sphere we must pay attention to the communication dimension of politics and political economy. In this case, the process of inclusion and exclusion in the public domain should also be considered can assess whether the public domain corrupt situation ambiguity.
\end{abstract}

Keywords: social media, conventional media, democratization, public sphere, corruption..

\section{PENDAHULUAN}

\section{Latar Belakang}

Di era informasi saat ini, yang politis tidak hanya merembes ke dalam kehidupan kita melalui corong-corong media konvensional seperti televisi dan surat kabar. Media sosial semisal Twitter, Facebook, dan blog juga telah menjadi wahana utama dalam penyebaran wacana-wacana dan isu-isu bernilai politis. Berbeda dari produksi dan distribusi isu atau wacana melalui media konvensional, produksi dan distribusi isu atau wacana melalui media sosial dapat dikatakan lebih mengemansipasi. Melalui media sosial setiap orang kini berkesempatan menyuarakan langsung pandangan mereka dan melemparkannya ke ranah publik. Fasilitas media sosial ini barangkali berpotensi besar untuk mengintensifkan dan mengekstensifkan proses demokratisasi yang tengah terjadi.

Akan tetapi, bagaimanapun juga relasi antara kemunculan media sosial dengan peningkatan demokratisasi masih menjadi ihwal yang diperdebatkan dan membutuhkan banyak 
penjelasan. Benarkah media sosial berperan positif dan signifikan bagi demokratisasi di era teknologi informasi? Seberapa besar potensi yang dimiliki media sosial untuk menyokong proses demokratisasi? Persoalanpersoalan semacam ini aktual dan cukup urgen untuk kita perbincangkan, terutama karena proses-proses politis yang melingkupi suksesi kekuasaan di negeri kita melalui Pemilihan Umum (Pemilu) 2014 silam diwarnai maraknya lalu lintas isu dan wacana melalui media sosial. Begitu masifnya penggunaan media sosial pada kurun demokratisasi kita saat ini, hingga kita tak bisa menghindar dari tuntutan untuk mendapatkan jawaban mengenai relasi keduanya.

Dalam upaya memperoleh pemahaman yang lebih jernih tentang relasi antara media sosial dengan demokratisasi, tulisan ini bukan hanya akan berusaha mendedah aspek-aspek yang perlu kita perhatikan, tetapi juga mempertimbangkan kemungkinankemungkinan efek negatif media sosial terhadap demokrasi kita. Penulis berargumen, kita harus melihat relasi antara media sosial dengan proses demokratisasi pada pembentukan ranah publik (public sphere). Untuk menjelaskannya lebih rinci, pertamatama akan diuraikan tinjauan pustaka terkait fokus permasalahan, kemudian akan diuraikan konsepsi ranah publik menurut filsuf Jurgen Habermas dan korupsi ranah publik menurut ilmuwan politik Mark E. Warren. Pada bagian akhir tulisan ini akan dibahas kontekstualisasi pemikiran kedua tokoh tersebut dalam membaca dan menganalisis sepak terjang media sosial dalam demokratisasi Indonesia dewasa ini..

\section{Metode Penelitian}

Hingga kini para akademisi lintas disipliner yang menaruh perhatian pada media, komunikasi, dan politik masih berdebat menyoal signifikansi media-media sosial di ranah politik, terutama dalam proses demokratisasi di berbagai negara, baik negara maju maupun berkembang. Sebagian pendapat menilai positif peran media sosial dalam demokratisasi, bersikap optimistik, bahkan cenderung menunjukkan euforia. Salah satunya terlihat dari beberapa studi yang mengangkat peran sentral media sosial dalam revolusi di beberapa negeri Timur Tengah pada tahun 2011 yang kita kenal sebagai Arab Spring. Mereka berpendapat media sosial telah menjadi sarana yang efektif dalam menyebarluaskan gagasan-gagasan tentang kebebasan dan mengonsolidasi massa sehingga berujung pada revolusi menentang rezim anti-demokratis semisal rezim Hosni Mubarak di Mesir.

Di antara yang optimistik dengan kebangkitan media sosial adalah Shirky (2008; 2011) dan Papacharissi (2010). Menurut Shirky (2008), media sosial telah berperan memperkuat ide dan praktik kebebasan. Dengan media sosial kini siapa pun memiliki kebebasan berbicara dan menyatakan pendapat. Media sosial juga menyebarluaskan gagasan tiap-tiap orang hingga melampaui loyalitas dan membuat mereka terhubung satu sama lain. Dengan cara ini media sosial juga 
meningkatkan peluang untuk berserikat dan membentuk asosiasi.

Seirama dengan Shirky, Papacharissi (dalam Fuchs, 2013) juga menyambut kebangkitan media sosial di ranah politis dengan positif dan optimisme. Menurutnya media sosial telah memungkinkan ranah-ranah privat diekspresikan dengan tingkat otonomi dan fleksibilitas yang tinggi. Dengan demikian, ranah-ranah privat tersebut akhirnya terkoneksi satu sama lain dan tidak lagi saling tersisolasi, sehingga memungkinkan semua yang personal bernilai politikal.

Baik Shirky maupun Papacharissi memberikan penekanan pada kemampuan media sosial dalam mengintensifkan kebebasan individu, terutama kebebasan politis mereka, seperti menyatakan pendapat dan berbicara. Lebih jauh Shirky (2011) menegaskan, kebebasan individu yang diperkuat oleh media sosial ini takkan mungkin dibendung oleh rezim otoriter apa pun. Karena setiap rezim otoriter akan menghadapi dilema dihadapkan dengan kemajuan teknologi informasi. Di satu sisi, teknologi tersebut memungkinkan setiap orang memiliki dan mengekspresikan pendapat yang berbeda, bahkan bertentangan, terutama dengan pendapat yang direstui oleh rezim. Di sisi lain, menafikan teknologi tersebut justru akan berakibat buruk bagi rezim itu sendiri, terutama karena melemahkan perekonomian yang saat ini kian terintegrasi dengan teknologi informasi.

Selain pendapat yang positif dan optimistik di atas, akademisi lain tak sedikit yang lebih skeptis dalam memandang kemunculan media sosial dan signifikansinya di ranah politis.
Fuchs (2013), misalnya, cenderung meragukan signifikansi media sosial pada meletupnya Arab Spring. Studi yang dilakukan Lotan, Graeff, Ananny, Gaffney, Pearce dan Boyd (2011 dalam Fuchs, 2013) dengan menyurvei 168.663 tweets di Tunisia dan 230.270 tweets di Mesir pada kurun terjadinya revolusi memang menunjukkan bahwa jurnalis dan aktivis merupakan sumber utama tweets tersebut, sementara blogger dan aktivis merupakan kelompok yang paling aktif melakukan retweets. Akan tetapi, menurut Fuchs temuan ini sama sekali tidak menunjukkan bahwa "revolusi benar-benar dikicaukan via Twitter". Analisis terhadap temuan survei tersebut tak dapat menunjukkan bagaimana kicauan-kicauan tersebut memobilisasi massa untuk turun ke jalan; juga tak dapat menunjukkan seberapa penting Twitter bagi para aktivis yang turun ke jalan. Selain itu, pada Maret 2011 hanya 0,00158 persen dari populasi Mesir yang menggunakan Twitter (Murthy, 2013 dalam Fuchs, 2013).

Selain Fuchs, Gladwell (2010) dan Morozov (2010) juga termasuk yang skeptis terhadap signifikansi media sosial bagi revolusi. Keduanya berpendapat aktivisme di media sosial tak lebih dari aktivisme "semu". Berbeda dari aktivisme yang dilakukan secara fisik, aktivisme di media sosial dibangun dari ikatan asosiasi yang lemah. Selain itu, aktivisme ini dilakukan oleh mereka yang sebenarnya tidak mau "repot" dan "ambil risiko" dengan melakukan perlawanan fisik. Paling jauh, penyuaraan pendapat di media sosial hanya 
memberi orang-orang perasaan bahwa mereka terlibat dalam sebentuk aktivisme tertentu.

Terlihat bahwa di balik skeptisisme mereka, pendapat Gladwell dan Morozov sebenarnya menyiratkan kecenderungan melakukan romantisasi terhadap revolusi fisik. Kendati demikian, optimisme Shirky dan Papacharissi juga cenderung melakukan romantisasi, tetapi romantisasi bukan terhadap revolusi, melainkan terhadap potensi media sosial itu sendiri. Oleh karena itu, Fuchs (2013) menekankan pentingnya melakukan kajian mendalam untuk memahami dengan jernih potensi media sosial sekaligus batasan-batasan yang dimilikinya. Bagaimanapun juga, kini media sosial menjadi instrumen dengan peran yang mesti kita perhitungkan dalam pembentukan ranah publik (public sphere).

\section{HASIL DAN PEMBAHASAN}

Hingga kini, barangkali konseptualisasi ranah publik oleh Jurgen Habermas masih merupakan konseptualisasi yang paling sistematis dan amat kerap dikutip. Habermas (1989) sendiri menyatakan bahwa suatu kejadian atau acara dikatakan "publik" manakala terbuka untuk semua orang. Dengan kata lain, inklusivitas merupakan aspek fundamental dalam konsep kita mengenai "yang publik". Demikian pula dengan ranah publik, dikatakan publik karena siapa pun boleh bersuara di sana. Menurut Habermas (dalam Fuchs, 2013) ranah publik memiliki beberapa dimensi penting, yaitu (1) pembentukan opini publik, (2) aksesnya terbuka bagi semua warga, (3) tak ada kekangan dalam menyoal kepentingan umum,
(4) aturan umum dalam berelasi senantiasa dapat diperdebatkan. Konsep ranah publik Habermas memang bersandar pada pandangan bahwa tiap-tiap individu memiliki rasionalitas yang memadai untuk mengutarakan pendapat dan mempersoalkan pendapat-pendapat lain di ranah publik. Konsepsi yang sangat inklusif dan rasional ini kerap pula menjadi sasaran kritik. Dua di antaranya adalah kritik dari kelas pekerja dan kritik dari para feminis.

Menurut kelompok pengkritik yang pertama, konsepsi Habermas terlalu menekankan pada gerakan kaum borjuis sembari mengabaikan gerakan-gerakan lain yang lebih populis, terutama gerakan kaum buruh. Adapun kritik feminis menuduh konsepsi Habermas mengabaikan keberadaan kelompok-kelompok lemah atau minoritas, terutama perempuan. Menurut mereka ranah publik selalu saja menjadi ranah bagi laki-laki berpendidikan, sementara perempuan tereksklusi ke ranah privat dan tak memiliki suara pada urusanurusan publik.

Meski dikritik sedemikian rupa, sebenarnya pemikiran Habermas tak dapat kita pandang dengan perspektif senaif itu. Habermas tidak berhenti semata pada pernyataan bahwa ranah publik merupakan ranah yang inklusif dan sepenuhnya rasional. Habermas (1989) juga menekankan adanya dua aspek konstitutif bagi ranah publik, yakni komunikasi politik (political communication) dan ekonomi politik (political economy). Di dalam perdebatan di ranah publik, bukan hanya argumentasiargumentasi rasional yang bermain, tetapi juga sumber daya-sumber daya (terutama 
ekonomi). Terkait dengan aspek ekonomi politik, ranah publik sendiri mengalami kekurangan dalam hal prasyarat sosial bagi terciptanya kesetaraan peluang dalam mengakses ranah publik; di mana orang-orang dengan keterampilan tertentu dan "keberuntungan" dapat menguasai ranah publik (Habermas, 1989).

Mengadopsi pandangan Habermas di atas, Fuchs (2013) menilai banyak pengkaji internet terlalu asyik dengan dimensi komunikasi politik semata dari ranah publik, dan hanya sedikit yang menaruh perhatian pada dimensi ekonomi politiknya. Untuk dapat mengkajinya secara komprehensif, kedua dimensi ini harus diperhatikan. Fuchs (2013) menyatakan, dimensi komunikasi politik itu mencakup persoalan mengenai (1) akses universal—siapa yang memiliki akses dan menggunakan suatu situs untuk kepentingan komunikasi politik? (2) independensi-seberapa independen suatu situs dari kepentingan ekonomi dan negara? (3) kualitas diskusi politiknya-seberapa valid, inklusif, tulus, dan refleksif suatu diskusi politik online? Adapun dimensi ekonomi politik mencakup persoalan mengenai (1) kepemilikan-apakah kepemilikan suatu media dan sumber daya bersifat demokratis? (2) sensor-adakah sensor ekonomi atau politik? (3) eksklusiapakah suatu media terlalu merepresentasikan pandangan elite mereka dan tidak kritis terhadap pandangan tersebut? (4) produksi muatan politisnya-siapa yang memproduksi muatannya dan seberapa relevan atau berpengaruh muatan pesan tersebut?
Hanya dengan mencermati secara seksama kedua dimensi ranah publik di atas, kita dapat mempertimbangkan apakah ranah publik yang terbentuk sudah sesuai dengan yang diharapkan bagi sehatnya demokratisasi atau belum. Oleh karena, kondisi-kondisi ekonomi politik juga dapat memengaruhi ciri paling fundamental dari ranah publik, yakni inklusivitas. Jika inklusivitas ini terganggu, dapat dikatakan ranah publik tersebut korup (Warren, 2004). Bukan hanya untuk media konvensional seperti surat kabar dan televisi, hal ini juga berlaku untuk media sosial. Untuk mendapatkan gambaran yang lebih jelas tentang inklusivitas ranah publik dan bagaimana ia bisa korup, bagian berikutnya akan mendiskusikan pandangan Mark E. Warren mengenai korupsi politis, terutama di ranah publik.

\section{KORUPSI RANAH PUBLIK}

Tulisan ini dimulai sebenarnya dengan mempertanyakan relasi antara pesatnya teknologi komunikasi dan informasi (dalam bentuk termutakhirnya: media sosial) dengan proses demokratisasi terutama di negeri kita sendiri, Indonesia. Apakah media sosial benarbenar signifikan bagi demokratisasi di era teknologi informasi sekarang ini? Jika ia memiliki pengaruh yang signifikan, apakah pengaruh tersebut baik bagi proses demokratisasi yang sehat, atau justru memiliki efek samping yang merusak demokratisasi itu sendiri? Kini media sosial telah menjadi aparatus penting dalam pembentukan ranah publik kita. Agaknya tak seorang pun menafikan hal ini. Bahwa media 
sosial dan ranah publik yang dibentuknya telah menjadi lahan subur bagi pertukaran informasi, gagasan, wacana, nampaknya tak perlu kita mungkiri. Namun potensinya untuk melakukan mobilisasi adalah soal lain. Pada ihwal terakhir inilah, sebagaimana telah kita lihat pada uraian singkat di bagian tinjauan pustaka, para akademisi berbeda pandangan; sebagian cenderung berpandangan positif dan optimistis, sebagian lainnya cenderung skeptis.

Untuk dapat memahami relasi antara media sosial dengan demokratisasi, kita pun mesti menelaah terlebih dahulu posisi ranah publik dalam demokrasi. Fungsi apakah yang dijalankan ranah publik dalam demokrasi? Bagaimana pula fungsi tersebut dapat terganggu, menjadi korup, dan malah berefek negatif bagi demokrasi? Pandangan Mark E. Warren mengenai korupsi politis (political corruption) dapat membantu kita menjawab kedua pertanyaan ini. Menurut Warren (2004) konsepsi korupsi politis senantiasa melibatkan empat proposisi dasar:

Pertama, adanya seorang atau sekelompok individu yang dipercaya untuk mengambil keputusan atau tindakan kolektif. Dalam situasi yang sudah demokratis, bukan hanya instansi publik yang dipercaya memegang kekuasaan kolektif, tetapi juga asosiasi, korporasi, dan entitas-entitas lain yang berperan dalam pengambilan keputusan dan tindakan kolektif-“... in today's democracies, it is not only public officials who are entrusted with collective power, but also associations, corporations, and any number of other entities that contribute to collective decision making and collective action" (Warren, 2004: 332). Hal ini terjadi karena kekuasaan kolektif tidak lagi dikuasai oleh negara kuat dengan pemerintahan otoriter. Warren sendiri mengidentifikasi adanya empat arena di mana kekuasaan dalam demokrasi ini terdistribusi, yaitu negara, pasar, masyarakat sipil, dan ranah publik. Oleh karena itu, di keempat arena ini pula kita dapat mengidentifikasi adanya korupsi. Hal ini tentu berbeda dari pandangan selama ini mengenai korupsi yang cenderung state-oriented.

Kedua, adanya norma umum yang mengatur bagaimana individu atau kelompok menggunakan kekuasaan mereka dalam mengambil keputusan dan tindakan kolektif. Dalam demokrasi, setiap orang yang bakal terdampak oleh suatu keputusan atau tindakan kolektif memiliki hak dan kesempatan yang sama untuk berpartisipasi dalam pengambilan keputusan dan tindakan tersebut. Dalam pembangunan misalnya, hal ini nampak pada kian mengemukanya konsep pembangunan partisipatif yang menggantikan pembangunan yang "top-down”. Konsekuensi dari hal ini adalah, setiap tindakan kolektif harus mencerminkan tujuan yang telah disepakati bersama melalui proses pengambilan keputusan yang inklusif di mana semua orang yang berkepentingan diikutsertakan.

Ketiga, seorang atau sekelompok individu yang telah dipercaya justru melanggar norma tersebut. Gagasan Warren mengenai poin ini melampaui konsepsi legal-formal yang mendefinisikan norma yang dimaksud di tataran hukum positif. Bagi Warren, dalam 
demokrasi norma yang dilanggar oleh korupsi adalah inklusivitas di dalam keputusan dan tindakan kolektif. Oleh karena itu, korupsi erat kaitannya dengan proses eksklusi: orangorang korup menggunakan kendali mereka atas sumber daya untuk memperoleh keuntungan dengan merugikan orang-orang yang sengaja tidak dilibatkan dalam proses pengambilan keputusan atau tindakan kolektif. "Indeed, the very logic of corruption involves exclusion: the corrupt use their control over resources to achieve gains at the expense of those excluded in collective decision making or organization of collective actions" (Warren, 2004: 333).

Lebih jauh, korupsi mengandung kemunafikan (Warren, 2004: 333)—orang-orang korup mengaku menjunjung norma demokrasi, tapi sekaligus melakukan pelanggaran terhadap norma tersebut. Hal ini kerap kita lihat, misalnya, dari gelagat para pejabat korup yang mengaku-aku sebagai bagian dari sistem yang demokratis, memperjuangkan kepentingan rakyat, tapi diam-diam menggerogoti uang negara.

Keempat, pelanggaran terhadap norma itu biasanya menguntungkan individu atau kelompok yang bersangkutan dan merugikan kolektivitas. Keputusan, tindakan, atau pertukaran hanya dapat dinilai sebagai korup jika menguntungkan orang-orang yang dilibatkan dalam pengambilan keputusan atau tindakan, sekaligus merugikan setidaknya sebagian orang yang sengaja tidak dilibatkan dalam proses tersebut. Tesis utama Warren mengenai korupsi, yang membedakannya dari gagasan pemikir-pemikir lain mengenai korupsi, adalah korupsi politis ia definisikan sebagai eksklusi bemuka dua (duplicitous exclusion) (Warren, 2004; Warren, 2006). Dalam pengertian ini, korupsi selalu mensyaratkan eksklusi, tapi tidak semua eksklusi itu koruptif. Ada beberapa kondisi lain yang membuat sebentuk eksklusi koruptif, yakni bersifat munafik atau bermuka dua dan menguntungkan pihak tertentu sembari merugikan pihak lain. Warren (2004: 334) menjelaskan:

Exclusion (a) is a necessary but not sufficient condition for corruption. In addition, two other conditions are necessary: (b) A duplicity condition with regard to the norm of inclusion: The excluded have a claim to inclusion that is both recognized and violated by the corrupt. (c) A benefit/harm condition with regard to the consequences of exclusion: the exclusion normally benefits those included within a relationship and harms at least some of those excluded.

Konsep korupsi yang demikian juga dapat kita kenakan untuk mendiagnosis apakah suatu ranah publik korup atau tidak. Warren (2004) sendiri, sebagaimana telah disebutkan sebelumnya, memasukkan ranah publik sebagai salah satu domain di mana korupsi dalam demokrasi dapat terjadi. Di dalam demokrasi, ranah publik memainkan peran penting dalam pembentukan opini publik. Di ranah publiklah setiap warga memiliki hak dan kesempatan untuk mendayagunakan "kekuatan diskursif” (discursive force), yakni kemampuan untuk menggerakkan orang lain dengan mengutarakan klaim-klaim normatif 
atau faktual melalui argumentasi dan persuasi (Warren, 2004: 338). Di dalam ranah publik akan selalu terjadi konflik, namun konflik ini dilakukan dan dimenangkan bukan dengan adu pukul atau kekerasan, melainkan dengan cara-cara "deliberatif”-memperbincangkan suatu persoalan secara rasional dengan disokong argumentasi-argumentasi yang kuat. Pengelolaan konflik dengan cara seperti inilah yang sebenarnya menjadi jantung demokrasi.

Oleh karena itu, mengikuti alur berpikir Habermas, Warren pun menekankan arti penting karakter inklusif dari ranah publik. Integritas ranah publik bergantung pada kemampuannya untuk melibatkan dan memberikan kesempatan kepada setiap orang untuk berargumentasi dan melakukan persuasi. Siapa pun berhak turut berbicara, berpendapat, dan berusaha memenangkan cara pandangnya, tentu saja didasarkan pada alasan-alasan dan pertimbanganpertimbangan rasional. Lantaran di dalam demokrasi setiap orang dipersilakan memiliki dan mengungkapkan pendapat masingmasing, maka korupsi di ranah publik bukan berkaitan dengan benar-salahnya suatu pendapat (Warren, 2004: 338). Melainkan, korupsi di ranah publik terkait erat dengan proses deliberatif yang terjadi di sana. Mengutip Habermas, Warren (2004: 338) menyatakan bahwa proses deliberatif ini memiliki integritas manakala orang-orang dapat membuat klaim tentang kebenaran yang ia percayai dan berharap dapat memotivasi orang lain dengan kebenaran tersebut tanpa mereduksinya menjadi "jargon" yang dikemukakan semata-mata demi kekuasaan atau uang. Dengan demikian, suatu pengutaraan pendapat korup bukan karena pendapat itu salah atau keliru, tetapi karena ia mengandung "akal bulus" dan dimaksudkan untuk membelokkan, menyamarkan, atau mengaburkan suatu klaim agar dapat mengamankan kepentingan pribadi seseorang atau sekelompok orang.

\section{MEDIA, MEDIA SOSIAL, DAN RANAH PUBLIK KITA HARI INI}

Media konvensional (televisi, surat kabar, majalah, dan sebagainya) maupun media sosial (Twitter, Facebook, blog, dan sebagainya) hari ini agaknya sudah menjadi bagian dari kehidupan politik kita. Sejak pemilihan umum tahun 2004, 2009, hingga 2014, kemunculan calon-calon presiden pada iklan-iklan televisi ataupun surat-surat kabar di masa-masa kampanye menjadi hal yang lumrah. Tak hanya calon presiden, calon-calon kepala daerah yang akan berkompetisi dalam pemilukada (pemilihan umum kepala daerah) di berbagai daerah juga acap beriklan, bahkan di televisi atau surat kabar nasional. Selain itu, setidaknya pada pemilihan umum legislatif 2014 silam, nyaris semua calon anggota legislatif yang berkompetisi juga memiliki akun media sosial Twitter, Facebook, dan sebagainya, di samping blog yang berisi informasi-informasi mengenai mereka. Hingar-bingar di media sosial ini kian intensif pada pemilihan presiden setelahnya. Selama periode pemilihan presiden, baik calon presiden Prabowo Subianto maupun Joko Widodo menyesaki ranah publik kita, 
termasuk ranah publik yang terbangun dari jejaring media-media sosial.

Dengan adanya media sosial, produksi dan penyebaran informasi kini tidak lagi dikuasai oleh media konvensional. Siapa pun dapat memproduksi informasi atau wacana sendiri, kemudian menyebarluaskannya dengan cepat entah melalui blog seperti Wordpress, Blogspot, Tumblr; situs jejaring sosial seperti Facebook dan LinkedIn; microblog seperti Twitter; wiki seperti Wikipedia; maupun content sharing site seperti Youtube dan Instagram. Tak sulit bagi kita untuk mengatakan, kemunculan media-media sosial semacam ini membuat produksi dan pertukaran informasi lebih egaliter. Informasi tidak lagi dimonopoli oleh media-media konvensional yang dimiliki oleh orang-orang yang berkuasa atau bermodal besar. Tak mengherankan jika kemudian banyak kalangan menilai media sosial baik bagi peningkatan kebebasan individu, sehingga baik pula bagi proses demokratisasi. Akan tetapi, pada optimisme semacam inilah kita justru patut "curiga". Kita akan kembali pada poin ini nanti.

Selain menantang monopoli media-media konvensional, kemunculan media sosial juga memungkinkan bentuk-bentuk komunikasi yang lebih personal. Penyebaran informasi tidak lagi bersifat satu arah; dan bukan sekadar dua arah, tetapi informasi juga dipertukarkan "satu-satu". Selama masa kampanye dalam kurun pemilihan umum, misalnya, banyak politisi atau calon politisi yang memiliki akun personal di beberapa media sosial. Akun-akun ini tidak sekadar menyebarkan informasi-informasi seputar empunya akun, seperti curriculum vitae mereka, visi dan misi, program kerja, dan sebagainya, tetapi juga menanggapi secara langsung pertanyaan dan komentar-komentar dari pengguna media sosial lain. Dalam mekanisme seperti inilah komunikasi yang terjalin mengalami personalisasi dan menjadi bentuk komunikasi "satu-satu", dari satu person ke person lain. Dalam transaksi informasi via internet saat ini, personalisasi transaksi demikian menjadi proses yang amat diperlukan untuk membangun loyalitas konsumen informasi tersebut (Maes, 1999). Nyaris semua aktor di panggung perpolitikan kita saat ini berusaha mengefektifkan penggunaan media sosial untuk kepentingan mereka. Mulai dari pejabat pemerintah, partai politik, hingga para politisi memiliki akunakun media sosial yang secara langsung menghubungkan mereka dengan publik luas pengguna internet. Bahkan mantan Presiden Susilo Bambang Yudhoyono kerap memanfaatkan salurannya di Youtube untuk menyoal berbagai kebijakan yang dikeluarkan pemerintahannya maupun berita-berita seputar dirinya.

Dibandingkan dengan media konvensional, media sosial nampaknya lebih dapat menyediakan akses yang universal bagi komunikasi politik. Siapa pun, dari politisi terkemuka hingga seorang warga biasa, dapat mengakses situs-situs media sosial dan menggunakannya untuk berbicara dan menyatakan pendapat. Dengan kata lain, media sosial juga memberikan kepada "warga biasa" akses untuk masuk ke dalam ranah 
politis. Media sosial memberi akses, kemudian menghubungkan tiap-tiap orang melalui pertukaran isu dan wacana, sekalipun orangorang tersebut tidak pernah mengenal secara langsung satu sama lain. Dengan demikian, media sosial juga memungkinkan pembentukan asosiasi yang didasari kesamaan konsumsi gagasan dan wacana. Dibantu miniaturisasi perangkat komunikasi sehingga mudah dibawa-bawa dan digunakan, setiap pengguna internet lantas dapat terhubung terus-menerus dengan wacana yang tengah marak diperbincangkan. Beragamnya wacana yang beredar, pada gilirannya membuat mustahil penyeragaman cara pandang oleh satu rezim kekuasaan sehingga dapat dipahami jika banyak kalangan menilai media sosial dapat sedemikian "subversif" bagi pemerintahan otoriter. Bahkan, keberagaman pandangan akibat berhamburannya informasi di dunia maya sangat berpotensi membawa kita pada apa yang oleh Danujaya (2012) disebut "demokrasi disensus", yakni demokrasi yang hanya diwarnai keberagaman bahkan pertentangan gagasan, tanpa pernah ada konsensus yang paripurna.

Meski menjadi "tantangan” bagi monopoli media-media konvensional, bukan berarti media-media besar berkepentingan untuk meredam perkembangan media sosial. Justru, kini banyak saluran televisi dan surat kabar yang juga mengelola akun-akun media sosial mereka sendiri. Akun-akun ini menjadi instrumen yang cukup efektif untuk memperluas paparan informasi yang mereka produksi. Meski belum dilakukan survei, namun kita dapat menduga banyak informasi di media sosial direproduksi dari informasiinformasi yang dirilis oleh akun-akun mediamedia konvensional. Di Twitter, misalnya, kicauan yang paling banyak dikicaukan ulang (retweet) mengenai kabar teraktual biasanya bersumber dari akun-akun media konvensional ataupun portal-portal berita besar. Terkait hal semacam ini, meski media sosial membukakan akses kepada ranah publik yang egaliter, namun tetap ada ketimpangan. Pada kenyataannya pengaruh dari sejumlah kecil akun tetap mendominasi sirkulasi wacana tentang kejadian-kejadian teraktual di sekitar kita. Akun-akun media konvensional serta tokoh-tokoh terkemuka agaknya tetap memainkan peran utama dalam produksi dan distribusi wacana. Untuk konteks Twitter, jangan dilupakan pula keberadaan akun-akun ber-follower banyak yang biasa kita sebut "seleb Twitter".

Pada perkembangannya, akun-akun "seleb Twitter" bahkan mampu mengonversi jumlah follower mereka menjadi sumber daya ekonomis. Dengan banyaknya follower, mereka berkesempatan menjadi "buzzer", yakni akun-akun yang mematok sejumlah tarif untuk menyebarluaskan informasi pesanan yang dipesan oleh pihak-pihak tertentu. Sebagai "penyedia jasa mengiklankan", para buzzer terbilang cukup efektif. Tak mengherankan jika kemudian mereka pun amat dicari untuk menyebarluaskan pesanpesan politis para aktor politik, baik terangterangan maupun secara tersamarkan.

Hal berikutnya yang patut kita cermati, sebagai pembentuk ranah publik beberapa media di Indonesia juga terlihat gamblang 
afiliasinya dengan kubu-kubu politis tertentu. Terlebih para petinggi dari media-media tersebut juga merupakan tokoh dalam politik praktis negeri ini. Pada pemilihan presiden 2014 lalu, misalnya, terlihat jelas satu media atau grup media memiliki kecondongan pada kandidat presiden Prabowo Subianto, sementara media atau grup media lain lebih condong pada kandidat presiden Joko Widodo. Mereka dengan sendirinya akan cenderung meredam isu-isu yang berpotensi merugikan pihak yang dibelanya, misalnya dengan memberitakan isu tersebut dengan frekuensi sedikit, sekaligus dengan pengemasan yang meminimalkan provokasi. Sebaliknya, isu-isu yang berpotensi mencederai kubu lawan akan cenderung direproduksi secara intensif dengan pengemasan yang provokatif. Sensor internal di atas biasanya bekerja bersamaan dengan sebentuk eksklusi-media-media menjadi berkecenderungan merepresentasikan pandangan elite mereka, tidak kritis terhadap pandangan tersebut, sekaligus mencecar pandangan lawan dengan rasionalisasi dan justifikasi yang dicari-cari.

Dengan mencermati aspek-aspek di atas, yang memperlihatkan dimensi-dimensi ekonomi politik, di samping komunikasi politik, dari ranah publik, kita akan dapat menimbangnimbang dengan lebih komprehensif bagaimana sepak terjang media dan media sosial memengaruhi proses demokratisasi yang terjadi di dalam ranah publik kita. Bagaimanapun juga, dalam praktiknya penggunaan media sosial dalam iklim demokrasi selalu dilekati-atau berpotensi dilekati-kepentingan-kepentingan tertentu, terutama yang sifatnya politis dan ekonomis. Kita tak dapat melihat variabel kebebasan individu semata-mata (terutama kebebasan berbicara dan berpendapat) untuk menilai signifikansi media sosial bagi proses demokratisasi. Berbagai variabel lain yang lebih mencerminkan ekonomi politik juga mesti kita pertimbangkan. Mengikuti formulasi Warren, kini menjadi sebuah keperluan bagi kita untuk merefleksikan ranah publik hasil pengonstruksian media konvensional dan media sosial di negeri kita dengan mempertimbangkan dua hal: (1) apakah telah terjadi duplicitous exclusion di sana? dan (2) apakah eksklusi tersebut menguntungkan pihak-pihak tertentu sekaligus merugikan sebagian pihak lain? Jika kedua hal ini terjadi, dapat kita katakan media konvensional dan media sosial juga telah menyumbang pengorupsian ranah publik kita, dan dengan demikian, pengorupsian demokrasi kita. Koruptifnya ranah publik akan merusak demokrasi karena hal tersebut mencederai relasi antara penilaian publik (public judgments) dengan keputusan kolektif (collective decision) (Warren, 2004: 339).

\section{PENUTUP}

\section{Simpulan}

Apa yang telah diuraikan mengenai keberadaan media sosial di tengah-tengah proses demokratisasi di atas barangkali belum cukup komprehensif. Akan tetapi, uraian tersebut agaknya memadai untuk membantu kita melihat bagaimana perkembangan media sosial sebenarnya tidak serta-merta 


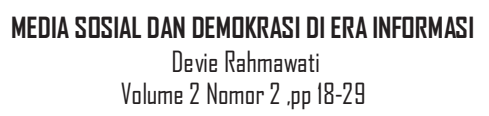

menggoyahkan dominasi media konvensional dan membuat ranah publik sepenuhnya egaliter. Lebih jauh, persinggungan yang dialami media sosial bukan sekadar dengan media konvensional, tetapi juga dengan berbagai kepentingan dan kekuasaan, baik kekuasaan politis maupun ekonomis. Oleh karena itu, sebagaimana yang diwanti-wanti oleh Fuchs (2013) dengan mengikuti pandangan Habermas, tak hanya dimensi komunikasi politik yang mesti kita perhatikan dalam menyelisik pembentukan ranah publik oleh media sosial, tetapi juga dimensi ekonomi politiknya.

\section{Saran}

Cara analisis yang ditawarkan Fuchs, yang mencoba mengakomodasi kedua dimensi tersebut, juga dapat membantu kita untuk menilai apakah ranah publik yang tercipta dari media sosial tersebut koruptif atau tidak.Jawaban pasti atas kedua pertanyaan ini tentu saja membutuhkan penelitian lebih lanjut dan komprehensif, dan jauh melampaui cakupan artikel ini. Namun setidaknya, artikel ini telah berupaya mengemukakan persoalan tersebut agar dapat menjadi perhatian kita bersama.

\section{DAFTAR PUSTAKA}

Danujaya, Budiarto (2012), Demokrasi Disensus: Politik dalam Paradoks, Jakarta: Gramedia.

Fuchs, Christian (2008), Internet and Society: Social Theory in the Information Age, London, New York, Routledge.

------ (2013), Social Media: A Critical Introduction, Los Angeles, London, New Delhi, Singapore, Washington DC, SAGE Publications.

Fuchs, Christian and Marisol Sandoval, eds. (2014), Critique, Social Media and Information Society, New York, Routledge.

Gladwell, Malcolm and Clay Shirky (2011), "From Innovation to Revolution: Do Social Media Make Protests Possible?" in Foreign Affairs 90 (2): 153-154.

Habermas, Jurgen (1989), The Structural Transformation of the Public Sphere, Cambridge, MIT Press.

Maes, Pattie (1999), "Smart Commerce: The Future of Intelligent Agents in Cyberspace," in Journal of Interactive Marketing 13(3).

Morozov, Evgeny (2010), The Net Delusion: How not to Liberate the World, London, Allen Lane.

Shirky, Clay (2011), “The Political Power of Social Media,” in Foreign Affairs 90 (1): 28-41.

Warren, Mark E. (2004), "What Does Corruption Mean in a Democracy?” in American Journal of Political Science 48 (2): 328-343.

(2006), "Political Corruption as Duplicitous Exclusion," in Political Science and Politics 37

(4): 803-807. 